\title{
A student made MOOC for medical students during the SARS-CoV-2 pandemic.
}

\author{
David Ramirez ${ }^{1 *}$ \\ 1 Grupo de Epidemiología Clínica de Colombia; david.ramirez01@uptc.edu.co, \\ https://orcid.org/0000-0003-4706-2703 \\ * Correspondencia: david.ramirez01@uptc.edu.co
}

Recibido: 25-7-2020; Aceptado: 6-8-2020; Publicado: 7-8-2020

\begin{abstract}
Background: Latin America was one of the last regions of the world to become affected by the COVID-19 pandemic. As a response to the emergency, virtual education was implemented in almost every country of the region. (2) Methods: A massive open online course (MOOC) about epilepsy was made using only open access software and platforms following the International League Against Epilepsy competence-based domains for epileptology teaching. (3) Results: 250 healthcare students from 8 different Latin American countries enrolled in the course and only 17.2(\%) of them had previously participated in courses like this one. This course had a completion rate of $37.2(\%)$ and, of the students that completed the course, $98.3(\%)$ would participate in courses like this in the future. (4) Conclusion: MOOCs can be easily implemented as a powerful pedagogic strategy during the COVID-19 pandemic and can have a positive impact not only in its proposed learning objectives but it can help in closing the gap that prevent Latin American healthcare students to acquire actively knowledge trough them.
\end{abstract}

Keywords: COVID-19; Quarantine; Epilepsy; Latin America.

Resumen: (1) Antecedentes: América Latina fue una de las últimas regiones del mundo en verse afectada por la pandemia de COVID-19. Como respuesta a la emergencia, se implementó la educación virtual en casi todos los países de la región. (2) Métodos: Se realizó un curso en línea abierto masivo (MOOC) sobre epilepsia utilizando solo software y plataformas de acceso abierto, siguiendo las competencias de la Liga Internacional contra la Epilepsia para la enseñanza de la epileptología. (3) Resultados: 250 estudiantes de salud de 8 países latinoamericanos diferentes se inscribieron en el curso y solo el 17.2 (\%) de ellos habían participado previamente en cursos como este. Este curso tuvo una tasa de finalización de 37.2 (\%) y, de los estudiantes que completaron el curso, 98.3 (\%) participaría en cursos como este en el futuro. (4) Conclusión: los MOOC se pueden implementar fácilmente como una estrategia pedagógica poderosa durante la pandemia de COVID-19 y pueden tener un impacto positivo no solo en sus objetivos de aprendizaje propuestos, sino que pueden ayudar a cerrar la brecha que impide que los estudiantes de salud latinoamericanos adquieran activamente conocimiento a través de ellos.

Palabras clave: COVID-19, cuarentena, epilepsia, Latinoamérica

\section{Introduction.}

Latin America was one of the last regions of the world to become affected by the COVID-19 pandemic. When it happened its different governments started implementing measures of hygiene, social distancing and quarantine that affected almost every aspect of the lives of their inhabitants. One of these aspects was 
education. Every country of the region took action on the matter and the restrictions ranged from the complete suspension of the classroom classes to the implementation of virtual technologies and strategies to continue with its academic programs(1). This opened a great opportunity to discover and innovate in virtual education. One of these innovative tools for virtual education are the massive open online courses (MOOCs) which are often free of charge (2) and can reach massive, as its name implies, amounts of people. Indeed, the most popular MOOC has reached more than 2.5 million people from very diverse backgrounds (3), This technology has also been implemented in formal medical education curriculums (4-6) and even the world health organization (WHO) has taken advantage of this technology to disseminate knowledge and reach a vast amount of healthcare professionals and students in times of the new coronavirus disease of 2019 (COVID-19) (7). These video based courses are not only specially relevant and useful in this time where quarantines and virtual education has become the new normality for many medical students, but also has been proved to be equally effective when compared to live lecture courses (8).

The International League against epilepsy (ILAE) in 2014 created the epilepsy education task force with the objective to create a web-based virtual campus to teach about epilepsy on a competence-based approach. Although this goal has not been reached yet, they had published what they consider should be the learning domains that should be teach in epilepsy (9) for healthcare professionals involved in the care of people with epilepsy. Using these domains proposed by the ILAE, a MOOC on epilepsy was made for Latin American healthcare students during the COVID-19 pandemic.

The main objectives of this manuscript are to describe the demographic characteristics of the participants of an epilepsy student made MOOC and to mention a methodology for the production of MOOCs using only open and free tools.

\section{Methods}

\subsection{The MOOC.}

A seven-week MOOC about the principles on diagnosis and management of epilepsy was made using open source platforms and software. The MOOC was divided into 5 main topics based on a competence-based curriculum in epileptology published previously (9) by the ILAE (Table 1).

Table 1. Epilepsy MOOC curriculum.

\begin{tabular}{|c|c|c|}
\hline Primary topics & Secondary topics & $\begin{array}{c}\text { Length } \\
\text { (mm:ss) }\end{array}$ \\
\hline Pathophysiology of epilepsy & Epileptogenesis; Ictogenesis & $25: 24$ \\
\hline $\begin{array}{c}\text { Non-epileptic paroxysmal } \\
\text { events }\end{array}$ & Psychogenic Nonepileptic Seizures & $49: 55$ \\
\hline $\begin{array}{c}\text { Principles of } \\
\text { electroencephalography }\end{array}$ & $\begin{array}{c}\text { Differential amplification; common } \\
\text { EE montages; Normal EEG patterns; } \\
\text { Epileptiform discharges } \\
\text { characteristics }\end{array}$ & $74: 10$ \\
\hline $\begin{array}{c}\text { ILAE 2017 seizure } \\
\text { classification }\end{array}$ & Diagnostic levels of epilepsy & $61: 15$ \\
\hline
\end{tabular}




\begin{tabular}{|c|c|c|}
\hline $\begin{array}{c}\text { Pharmacologic principles of } \\
\text { epilepsy treatment }\end{array}$ & $\begin{array}{c}\text { Action potentials; Blood brain barrier; } \\
\text { Pharmacological and } \\
\text { pharmacodynamic review of } \\
\text { Antiepileptic drugs }\end{array}$ & $52: 11$ \\
\hline
\end{tabular}

Each lecture consisted of a topic review presented with PowerPoint slides with the lecturer voice-over and freehand drawings using a digital tablet, also known as Khanstyle lecture production (Figure 1).

Figure 1. Lecturer drawing over a PowerPoint slide used in the MOOC also known as the Khan-style lecture production.

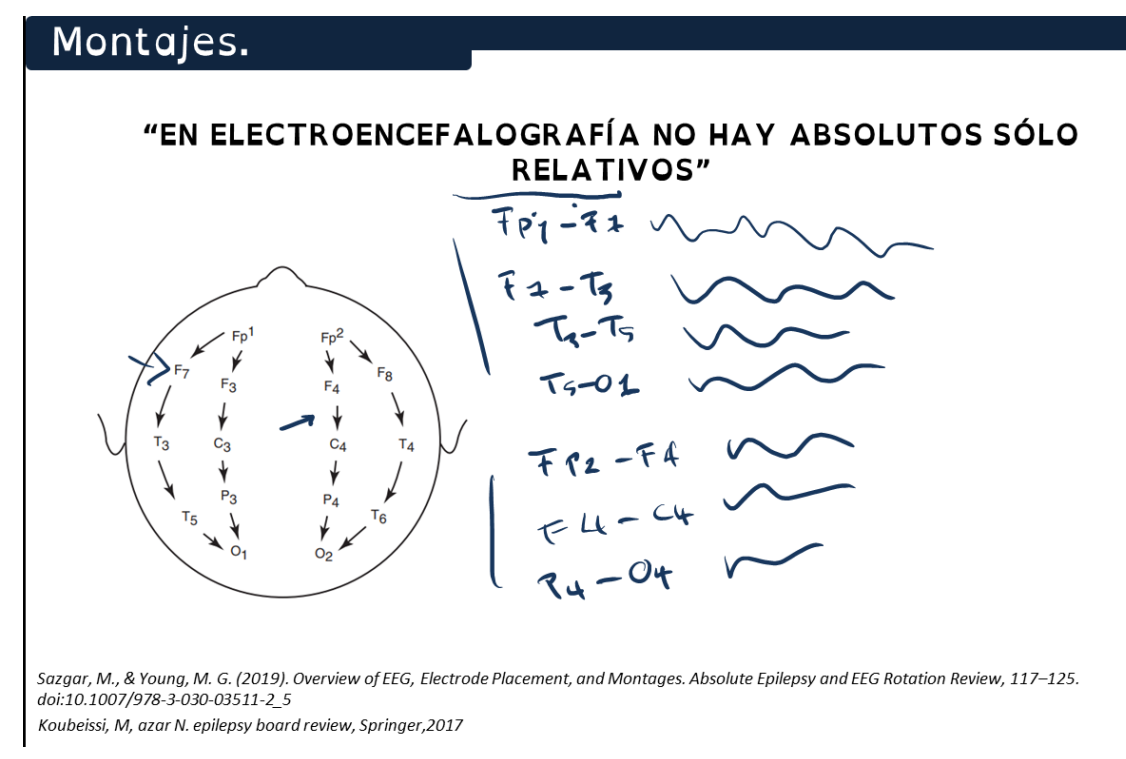

Each lecture was presented via YouTube live and the recorded lecture was then upload to the Google classroom were the MOOC was hosted. The screen recording and broadcast through YouTube was made using Open Broadcaster Software, an open and free software. In Google classroom during the seven weeks the MOOC lasted, all the students had access to the lectures recordings, the scientific articles used in the topic review, a forum and a five-question review test for each lecture which was made using Google forms.

\subsection{The participants.}

The MOOC was promoted trough the social networks Whatsapp and Instagram. All the participants signed-up through a Google Form where a record of their personal data was made. Using the e-mails recorded with the forms they were enrolled in the Google classroom where the MOOC were hosted. After the last lecture, the participants were invited to answer a similar form in order to compare the data from the cohort who signed up for the MOOC and those who finished it. In the forms, the participants were asked for their permission for the use of their personal data and only the personal data of the participants which agreed is presented in this manuscript.

\section{Results}

A total of 250 healthcare students signed up in the epilepsy MOOC. The demographic characteristics of the participants are summarized in the Table 2 , from a total of 8 different Latin American countries (Figure 2). 
Table 2. Characteristics of the students which signed up for the MOOC.

\begin{tabular}{|c|c|}
\hline Characteristics & Number (\%) \\
\hline Gender & $172(69 \%)$ \\
\hline Female & $78(31 \%)$ \\
\hline Male & \\
\hline Academic background & $246(98.4 \%)$ \\
$3(1,2 \%)$ \\
\hline $\begin{array}{c}\text { Medical students } \\
\text { Medical doctors }\end{array}$ & $1(0.4 \%)$ \\
\hline Nursing students & $68(27.2 \%)$ \\
\hline Age & $176(70.4 \%)$ \\
\hline $16-20$ & $6(2.4 \%)$ \\
\hline $21-30$ &
\end{tabular}

Figure 2. Heat-map showing the countries of origin of the participants of the MOOC.

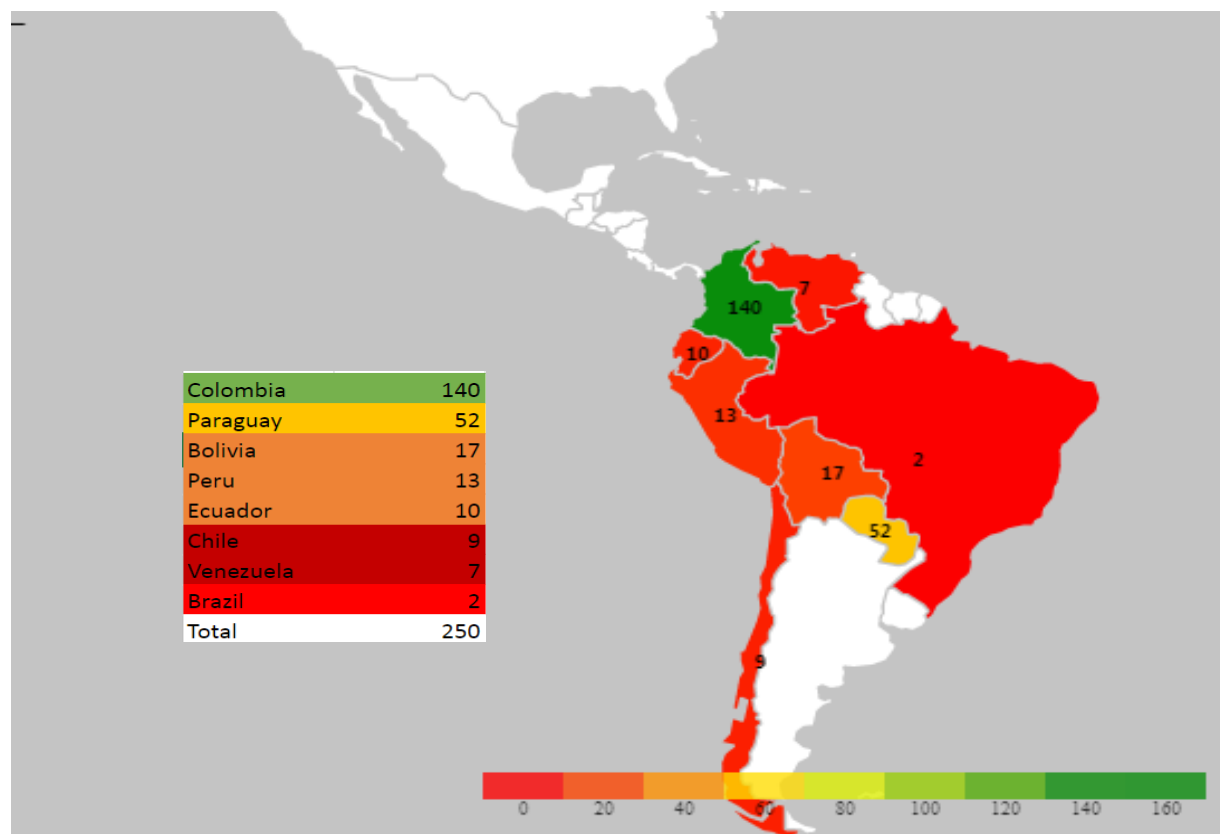

From these 250 participants only 43 (17.2\%) of them had previously participated in other MOOCs. When asked about the length of the lectures after the completion of the MOOC, 94\% of the participants who finished the MOOC said they had an optimal length (Figure 3) and 98.3\% of them agreed that they would participate in MOOCs in the future. This epilepsy MOOC had a completion rate of $37.2 \%$ for a total of 93 participants. 
Figure 3. Opinion upon the lecture length from the participants which finished the MOOC.

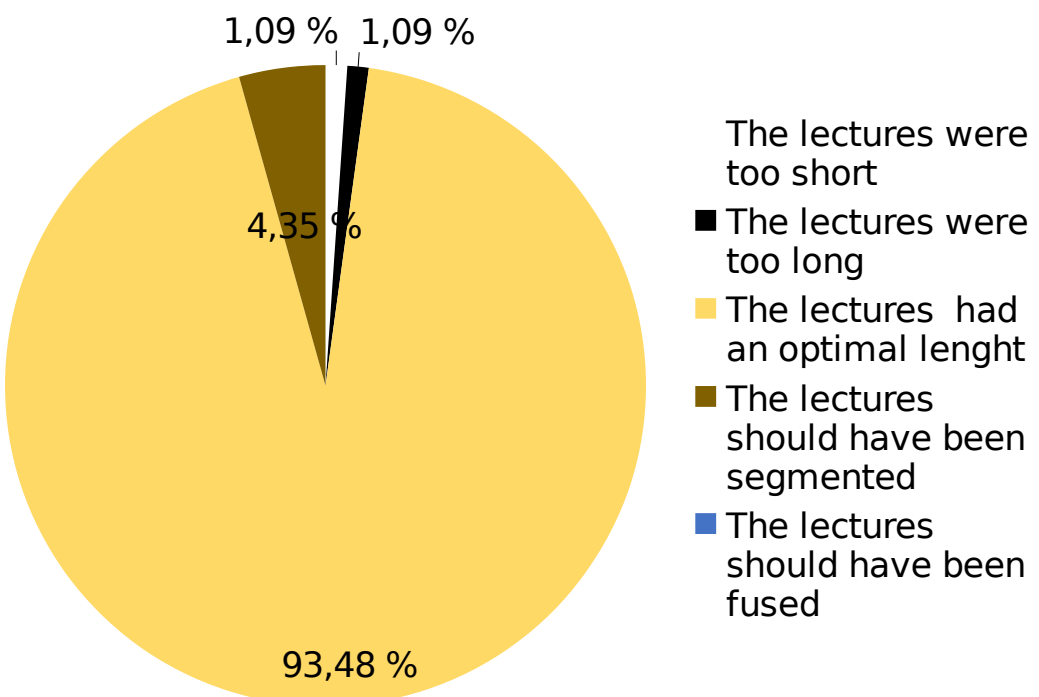

\section{Discussion}

Student-made content for students are not novel; nevertheless, with the implementation of information and communications technologies this content can reach more than the author's own cohort and it can break boundaries that were unbreakable before. The geographical distance can be shortened and high quality resources can be accessible for almost anyone with an internet connected device (10). MOOCs are part of these technologies since they were introduced in 2008 as a concept by Cormier and Alexander and it has become an immensely popular tool since then (11). This experience making a peer taught epilepsy MOOC represents an important statement on how Latin American students, which are usually a hard population to reach with conventional MOOC technologies $(10,12)$ are indeed reachable and receptive to learning using this tool. One of the main determinants that acts as a barrier to the implementation of MOOCs in Latin American countries is the language barrier. In the report of the data from a WHO MOOC on COVID-19, the main source of enrolments was through their Spanish version of the MOOC (7). This shows how you can reach this population if you break this linguistic barrier. Similarly, this epilepsy MOOC was offered entirely in Spanish and as a result, only two students from Brazil signed up. These two students lived in border cities with Spanish speaking countries so they spoke Spanish as a second language and overcame this barrier.

This MOOC had a completion rate of $37.2 \%$, which may seem modest at a first glance. However, MOOCs are known to suffer low completion rates, with average rates of completion of less than $10 \%$ and as low as $6.5 \%(13-14)$. Our success may be due to two main factors: 1) we awarded free certificates for those who finished the MOOC (as stated by the completion and approval of the weekly tests) and 2) we used a highly engaging methodological style, the Khan production style. This style consists of a full screen video with the lecturer drawing freehand on a digital tablet, this method had shown more engagement from students compared with other methods of lecture production like having PowerPoint slides only (15). The second methodological aspect that may have had a positive impact on the completion rate may be the selfpacing nature of this MOOC. Students could revisit any topic at any time as long as it was in the 7-week period the MOOC was open, which is associated with greater learning (16). The third methodological aspect of this MOOC that may have had a positive influence in the completion rate is the length of the lectures. Lectures in this 
MOOC were an average of 52 minutes. This is unconventional for MOOCs and it is a statement that may contradict previous findings that show otherwise (15). However, $94 \%$ of the students who finished this MOOC affirmed that the lecture length was optimal. This result may be biased because we only use the data of those who finished the MOOC which may be more pleased with the MOOC in comparison with those who dropped from the MOOC without finishing it.

Only $17.2 \%$ of the participants had previously participated in other MOOCs, but when the students who finished the course were asked if they would participate in MOOCs again, $98.9 \%$ of them said they would. This can show us that when breaking the barriers that keep the gaps for Latin American Students to acquire knowledge trough MOOCs we can start building a MOOC-participative culture in them.

\section{Conclusions}

- MOOCs can be easily implemented as a powerful pedagogic strategy during periods of social disruption, such as the COVID-19 pandemic.

- MOOCs can have a positive impact not only in its proposed learning objectives but can also help in closing the gap that prevent Latin American healthcare students from actively participating in them.

- There are multiple open and free tools which can be used to produce impactful teaching resources including producing and hosting MOOCs for medical education.

Financiación: This project received no funding.

Agradecimientos: The author would like to acknowledge Ana María Riveros Betancourt for proofreading this manuscript and her invaluable advice and Valentina Parra and Sofia Muñoz, two medical students which helped with the logistics for the making of the Massive online open course this paper is based on.

Declaración de conflicto of interés: "El autor declara no tener ningún conflicto de intereses."

\section{Referencias}

1. UNESCO. Monitoring school closures. Updated 2020 may 8; Cited 2020 jun 12. https:// en.unesco.org/fieldoffice/santiago/covid-19-education-alc/monitoring

2. Young G, McLaren L, Maden M. Delivering a MOOC for literature searching in health libraries: evaluation of a pilot project. Heal Inf Libr J. 1 de diciembre de 2017;34(4):312-8. https://pubmed.ncbi.nlm.nih.gov/29265692/

3. Oakley BA, Sejnowski TJ. What we learned from creating one of the world's most popular MOOCs. npj Sci Learn. 2019 Dec 14;4(1):1-7. https://www.nature.com/articles/ s41539-019-0046-0

4. Robinson R. Delivering a medical school elective with massive open online course (MOOC) technology. PeerJ. 2016;2016(8). https://pubmed.ncbi.nlm.nih.gov/27602301/

5. Swinnerton BJ, Morris NP, Hotchkiss S, Pickering JD. The integration of an anatomy massive open online course (MOOC) into a medical anatomy curriculum. Anat Sci Educ. 2017 Jan 1;10(1):53-67. https://pubmed.ncbi.nlm.nih.gov/27315160/

6. Maxwell WD, Fabel PH, Diaz V, Walkow JC, Kwiek NC, Kanchanaraksa S, et al. Massive open online courses in U.S. healthcare education: Practical considerations and lessons learned from implementation. Curr Pharm Teach Learn.2018 Jun 1;10(6):736-43. https://pubmed.ncbi.nlm.nih.gov/30025774/

7. Utunen H, Ndiaye N, Piroux C, George R, Attias M, Gamhewage G. Global reach of an online covid-19 course in multiple languages on openwho in the first quarter of 2020: Analysis of platform use data. J Med Internet Res. 1 de abril de 2020;22(4). https://www.jmir.org/2020/4/e19076/ 
8. Brockfeld T, Müller B, de Laffolie J. Video versus live lecture courses: a comparative evaluation of lecture types and results. Med Educ Online. 2018 jan 1;23(1). https://www.ncbi.nlm.nih.gov/pmc/articles/PMC6300084/

9. Blümcke I, Arzimanoglou A, Beniczky S, Wiebe S. Roadmap for a competency-based educational curriculum in epileptology: report of the Epilepsy Education Task Force of the International League Against Epilepsy. Epileptic Disord. 2019 apr 1;21(2):129-40. https://pubmed.ncbi.nlm.nih.gov/30892268/

10. Liyanagunawardena, T., Williams, S. and Adams, A. (2013) The impact and reach of MOOCs:a developing countries' perspective. eLearning Papers (33). ISSN 1887-1542 http://centaur.reading.ac.uk/32452/1/In-depth_33_1.pdf

11. Aboshady O, Aboshady O. Massive Open Online Courses and Medical Education. Int J Med Students. 4 de agosto de 2014;2(3):142-3. https://ijms.info/IJMS/article/view/185

12. Harder B. Are MOOCs the future of medical education? BMJ;346(apr26;2). https://www.bmj.com/content/346/bmj.f2666

13. Jordan K. Massive open online course completion rates revisited: Assessment, length and attrition. Int Rev Res Open Distance Learn. 2015 jun 19;16(3):341-58. http://www.irrodl.org/index.php/irrodl/article/view/2112

14. Khalil HEM. MOOCs Completion Rates and Possible Methods to Improve Retention - A Literature Review - Learning \& Technology Library (LearnTechLib). En: In J Viteli \& M Leikomaa. Tampere, Finland: Association for the Advancement of Computing in Education (AACE); 2014. https://www.learntechlib.org/primary/p/147656/

15. Guo PJ, Kim J, Rubin R. How video production affects student engagement: An empirical study of MOOC videos. En: L@S 2014 - Proceedings of the 1st ACM Conference on Learning at Scale. New York, New York, USA: Association for Computing Machinery; $2014 . \quad$ p. $41-50$. https://dl.acm.org/doi/10.1145/2556325.2566239

16. Carvalho PF, Sana F, Yan VX. Self-regulated spacing in a massive open online course is related to better learning. npj Sci Learn. 16 de diciembre de 2020;5(1):1-7. https://www.nature.com/articles/s41539-020-0061-1

(C) 2020 por los autores. Enviado para su publicación en acceso abierto bajo los términos y condiciones de la licencia Creative Commons Attribution (CC BY) (http://creativecommons.org/licenses/by/4.0/). 